\title{
Physiological Parameters in the Equine Competitions Rodeo Cow in the Southern State of Piaui, Brazil
}

\author{
Wéverton José Lima Fonseca ${ }^{1}$, Carlos Syllas Monteiro Luz ${ }^{2}$, Wéverson Lima Fonseca ${ }^{3}$, Gioto Ghiarone Terto e \\ Sousa $^{4}$, Darlon José Alves de Sousa ${ }^{5}$, Tatiano Ribeiro dos Santos ${ }^{6}$, Laylson da Silva Borges ${ }^{7}$, Leandro de Oliveira \\ Guerra $^{8}$, Tiago de Oliveira Sousa ${ }^{9} \&$ Severino Cavalcante de Sousa Júnior ${ }^{10}$ \\ ${ }^{1}$ Colleger PIBIC/CNPq - Undergraduate Course of Bachelor of Animal Science - UFPI/CPCE, Brazil \\ ${ }^{2}$ M.Sc of graduate in Animal Science, Department of Animal Science - UFPI/CPCE, Brazil \\ ${ }^{3}$ Colleger PIBIC/CNPq - Undergraduate Course Bachelor in Agricultural Engineering - UFPI/CPCE, Brazil \\ ${ }^{4}$ Teacher at the Institute of Higher Education Multiple IESM / Timon, Maranhão, Brazil \\ ${ }^{5}$ Zootechnician, State University of Piauí, Brazil \\ ${ }^{6}$ Agricultural Engineering - UFPI/CPCE, Brazil \\ ${ }^{7}$ Colleger PIBIT/CNPq - Undergraduate Course of Bachelor of Animal Science - UFPI/CPCE, Brazil \\ ${ }^{8}$ Undergraduate Course of Bachelor of Animal Science - UFPI/CPCE, Brazil \\ ${ }^{9}$ Undergraduate in Agronomy - UFPI/CPCE, Brazil \\ ${ }^{10}$ Doctor, teacher. DZO/UFPI/CPCE, Brazil \\ Correspondence: Wéverton José Lima Fonseca, Undergraduate Course of Bachelor of Animal Science, Federal \\ University of Piauí, Bom Jesus, PI, 64900-000, Brazil. Tel: 55-89-9939-3260. E-mail: wevertonsbz@yahoo.com
}

\author{
Received: February 8, 2014 Accepted: March 18, 2014 Online Published: April 15, 2014 \\ doi:10.5539/jas.v6n5p80 URL: http://dx.doi.org/10.5539/jas.v6n5p80
}

\begin{abstract}
This research was conducted in the town of Redenção of Gurguéia in the southern region of the state of Piauí. The region has a semi-arid tropical climate type, which corresponds to the high temperatures and dry climate, in the period of summer rainy season dragging for fall, common to all regions of northeastern Brazil. 27 adult crossbred horses race quarter mile aged (5-16 years) were used, nine males with white fur, with nine -nine sorrel coat with red fur. Heart rate (HR) and respiratory rate (RR) were performed. Thermal environment in a black globe with the purpose of recording the internal temperature of the animal at the beginning and end of each time of sampling, to calculate the rate of global temperature and humidity (BGT) was installed. The variations between the characteristics measured were significantly different $(\mathrm{P}<0.05)$ between the two rounds of collections that corresponds to the 1st morning shift (T1) and 2 afternoon shift (T2) for heart rate (HR), respiratory rate (RR) and the rate of global temperature and humidity (BGT). The respiratory rate (RR) was positively correlated with FC (0.65).
\end{abstract}

Keywords: horse, thermal stress, physiological parameters, quarter mile

\section{Introduction}

The horses used for expositions are subjected to take exercise with high intensity, but short period of time, which consists of a fast start, the route changes and abrupt stops during the overthrow of the Ox. The Rodeo Cow is an equestrian sport highly widespread in Brazil, especially in the Northeast region (Lopes, Batista, \& Day, 2009).

Competitive sports high yield and increased exercise load trigger injuries resulting from training, similar to those that occur in human athletes, causing loss of performance which can be minimized with individualized and specific training for each type of physical activity or individual limitations each animal (Marques, 2002).

Thus, over the years there is a growing appreciation of horses that develop during sports practices and competitions Rodeo Cow climate conditions, due to the work conducted during the day in extremely hot environment. High temperatures coupled with exercise can lead animals to heat stress by activating homeothermy responsible for regulating mechanisms, maintenance of uniform temperature in an animal. 
Second (Silva, 2005), environmental variables are stressors that act on the body as a whole, causing him to react in some way, and the results of this reaction can be evaluated by the behavior of the physiological variables that together give a measure of the voltage at which the animal is subjected.

With that animals behave like a thermodynamic system that continuously exchange energy with the environment. Whereas animal welfare, some factors that are related to the behavior births on the slopes, as can be observed relations man - animal, the environment (temperature, humidity, height, solar radiation, noise pollution), and the management systems, and other physical state (Mota, 2000).

Activities in these horses have a recognized ability for sports practices are extremely important and required during competitions Rodeo Cow. The low-intensity exercise performed by a longer period of time is considered to be more affective to increase resistance to high-intensity exercise performed for a short period of time (Trilk, 2002).

They are subjected to strenuous exercise which becomes critical to the recognition of your skills and abilities as a result of the different stages of competitions. Adding variables to unfavorable environmental conditions of life of the animal, such as noise pollution, exposure to high ambient temperatures, contact with other unfamiliar animals and other species, providing food and water out of the rut, among numerous other factors, presents a framework that honey combrece physical and psychological injuries (Angeli, 2005).

Because of this, the mounts basically formed by native horses were replaced by animal's better lineage and, with investments in the construction of so-called "parks Rodeo Cow" there was standardization and improvements in race conditions of the tests. Thus, as regards the acquisition of animals and prizes offered, the sport began to involve large investments (Lopes, Batista, \& Day, 2009). For horses, we can cite several factors that influence directly in the animal causing heat stress and thereby affecting the animal's body due to high temperatures, relative humidity, temperature and climate change, transport and thermal radiation.

All these agents can interfere with the performance of a horse athlete, because they are often aggressive, which promotes the organism, non-specific reactions and hence change the adjustment hormone secretion and physiological characteristics, thus requiring care special (Lopes, Batista, \& Day, 2009). Besides exercising much during the tests, the durations of each are very fast start, where horses are subjected to physical efforts to perform high intensity, but short time to its maximum supported by the body, changes in route and abrupt stops during the overthrow of the Ox.

High performance athletes, whether human or horse, are often compelled to exercise near maximum effort bearable by your body (Marc, Parvizi, Ellendorff, Kallweit, \& Elsaesser, 2000). The present study aimed to verify the parameters indicators of heat stress in horses in competitions Rodeo Cow in the state of Piaui.

\section{Materials and Methods}

The experiment was conducted in August 2012, the park Rodeo Cow of Redenção of Gurguéia, Southern State of Piaui. The experiment lasted for three consecutive days, starting from the first data collection 8:00 am until 12:00 which was the period when horses were in idleness. The second collection began at 14:00 hours until 18:00 hours which is the period where the horses were exercising physical activities.

The experimental design was completely randomized (CRD) with two treatments, where treatment 01 representation morning shift and 02 treatment regarding the afternoon shift. Were used 27 male animals of the equine species (Equus caballus) mongrel breed quarter mile were used, nine males with white fur, with nine - nine sorrel coat with red fur. Among the activities carried out in Rodeo Cow during the competitions, there is a need to compare physiological variables of the animals during the day in two shifts: 1st shift (T1), which is the period when the animal is at rest not exercising physical activities, or remains in a position of comfort before any exercise; horses to perform physical efforts with high intensity during competition in the 2 nd round (T2), based on the same variables measured, submitted.

The characteristics were examined for heart rate (HR) was achieved through the use of a medical stethoscope positioned on the left side of the thorax of the animal was recorded subsequently the frequency of heart beats per minute. The respiratory rate (RR), which consisted of direct observation of the counting of movements of the left flank of the animal in a minute. To calculate the rate of global temperature and humidity (BGT), was installed in the environment a black globe with the purpose of recording not only the air temperature, but also the effect of radiation, relative humidity, barometric pressure and wind effects at the beginning and end of each time of sampling.

The index Globe Temperature and Humidity (BGT) was according to the methods used by Morais et al. (2008), the following equation was used: 
Partial Vapor Pressure (Pp $\{\mathrm{ta}\})$

$\mathrm{Pp}=\mathrm{Ps}\{\mathrm{Ta}\}\{\mathrm{You}\}-\gamma(\mathrm{Ta}-\mathrm{Tu})$

being:

$\mathrm{Ps}\{\mathrm{Tu}\}=$ saturation pressure at temperature $\mathrm{Tu}(\mathrm{kPa})$;

$\gamma=$ psychrometric constant $\left(\mathrm{kPa} /{ }^{\circ} \mathrm{C}\right)$;

$\mathrm{Ta}=$ air or dry bulb $\left({ }^{\circ} \mathrm{C}\right)$;

$\mathrm{Tu}=$ wet bulb $\left({ }^{\circ} \mathrm{C}\right)$ temperature.

Index Globe Temperature and Humidity (BGT)

BGT Tg $=41.5+0.36+$ Tpo

being:

$\mathrm{Tg}=$ temperature of the globe thermometer $\left({ }^{\circ} \mathrm{C}\right) ;$

Tpo $=$ dew point temperature $\left({ }^{\circ} \mathrm{C}\right)$;

$41.5=$ constant.

All data collected were subjected to homogeneity of variance of the residual variance analysis and correlation between variables test. To compare the results of the Tukey test $(\mathrm{P}<0.05)$ was performed using the statistical package SAS version 9.3 (SAS Institute, 2003). Statistical analysis was performed by the method of least squares as (Harvey, 1960), based on the following model:

Yjklm $=\mu+A j+$ Hk + ITGUjkl + FRjkl + FCijkl ejklm

Being:

Yjklm = mth average;

$\mu=$ the overall mean;

$\mathrm{Aj}=$ random effect of the animal $\mathrm{j}-\mathrm{th}$;

$\mathrm{Hk}=$ the fixed effect of the kth before and after physical activity $(\mathrm{k}=\mathrm{M} 1, \mathrm{M} 2)$;

ITGUjkl = index Globe Temperature and Humidity collection of 1 - th, $\mathrm{k}$ - th time, animal jth;

$\mathrm{FRjkl}=$ respiratory rate of the $1-$ th collection, kth moment Animal jth;

$\mathrm{FCjkl}=$ heart rate of $1-$ th collection, kth moment, animal jth;

ejklm is the residue, including the random error.

\section{Results and Discussion}

To perform the physical activities of horses with high intensity, the energy required is provided through two combinations (via aerobic and anaerobic route). During the low-intensity physical activity, aerobic metabolism is primarily responsible for providing energy, and the achievement of physical activities in horses with high intensity, the supply of energy by anaerobic metabolism pathway becomes increasingly progressively greater. Second (Hinchcliff, 2002), while running about 30\% of energy requirements are supplied through anaerobic.

Considering the results obtained for the physiological parameters, we can observe a significant difference $(\mathrm{P}<0.05)$ for all traits (RR, HR, and BGT) providing increased after training in the second round in the afternoon. However, animals subjected to heat stress, showed increased respiratory rate (RR) after training $(69,40$ th $\mathrm{mov} / \mathrm{min})$ as one of the physiological mechanisms of heat loss by evaporation that can be influenced by several factors highlighting the air temperature and humidity of the environment, based on this result, the major mode of spread of this heat is sweating in horses (Freitas, 2005).

For animals that carry high intensity physical activity under conditions of high temperature and humidity loss in the ability of evaporative heat loss (heat loss) can occur. This result is explained by Paludo et al. (2002), justifying this feature to be the first line of defense physiological animal when subjected to heat stress, showing thus be subject to greater variation. Because these animals need to lose heat to maintain body temperature in the thermal neutral zone (Table 1). 
Table 1 . Mean respiratory rate, heart rate and rate of global temperature and humidity of crossbred horses race quarter mile during shifts (morning and afternoon) on the Redemption Gurguéia PI.

\begin{tabular}{lcc}
\hline \multirow{2}{*}{ Character } & In morning & In afternoon \\
\cline { 2 - 3 } & Turn 1 (T1) & Turn 2 (T2) \\
\hline FR (mov/min.) & $35,37^{\mathrm{b}}$ & $69,40^{\mathrm{a}}$ \\
HR (beats/min.) & $48,51^{\mathrm{b}}$ & $81,03^{\mathrm{a}}$ \\
BGT $\left({ }^{\circ} \mathrm{C}\right)$ & $82,87^{\mathrm{b}}$ & $85,51^{\mathrm{a}}$ \\
\hline
\end{tabular}

Means followed by the same letter in the line do not differ by Tukey test at $5 \%$ probability. FR = Respiratory Rate, $\mathrm{HR}=$ heart rate and index globe temperature and humidity (BGT).

Due to race Rodeo Cow have a high energy demand, pets require a high concentration of oxygen in the body, using the increase in respiratory frequency to meet this demand. According (Cunningham, 2004), it was found that even in mammals that do not pant like horses, evaporative heat loss through the respiratory tract increases during prolonged exercise.

As heart rate $(\mathrm{HR})$ showed a significant difference $(\mathrm{P}<0.05)$ suggests that this increase is associated with cardiovascular high-intensity exercise. Adaptability can be assessed by the animal's ability to adjust to environmental conditions averages, as well as climatic extremes (Paludo et al., 2002). The increase of maximum heart rate (HR) after the race ( $81.03 \mathrm{to} \mathrm{mov} / \mathrm{min}$ ) can be associated is due to the maximum intensity reached during physical activity performed by the animal relationship can be adopted as an index for evaluation of fitness. Second (Ridgway, 1994) heart rate can be used as an indicator to determine the level of compliance and the ability of the animal to continue work or exercise.

The high values for the index black globe temperature and humidity (BGT) show statistically significant differences for the two rounds (T1 and T2), for when the animal was in idleness and after physical activity, which presented the highest average runoff afternoon $\left(85,51^{\mathrm{a}}\right)$ corresponding to the period in which the animals were developing physical activities, ie after training. Because these values are affected to the moments in which they were collected because Rodeo Cow has no set time to start and end the competition. Second (Oliveira et al., 2008), is characterized as the thermal environment proved to room temperature which can be considered above the thermal comfort zone for many domestic animals, even goats (Brazil, Wechsler, Baccari Jr., Gill, \& Bonassi, 2000).

According to Table 2 we can see that the heart rate $(\mathrm{HR})$ presented loves a significant difference $(\mathrm{P}<0.05)$ for the two colors (red and white) in relation to the sorrel color, providing greater value for the red color (70.44 to). Based on this result, it can be explained that red or black hair absorbs a larger proportion of the heat by infrared waves, when compared with equines chestnut hair color, which is characterized by having high temperatures thereby increasing blood flow the body surface (Silva, 2000).

Table 2. Mean respiratory rate, heart rate and rate of global temperature and humidity of crossbred horses race quarter mile during shifts (morning and afternoon) on the Redenção do Gurguéia PI.

\begin{tabular}{lccc}
\hline \multirow{2}{*}{ Character } & \multicolumn{3}{c}{ Color Markings } \\
\cline { 2 - 4 } & Red & Chestnut & White \\
\hline FR (mov/min.) & $57,6^{\mathrm{a}}$ & $52,44^{\mathrm{a}}$ & $47,11^{\mathrm{a}}$ \\
HR (beats/min.) & $64,44^{\mathrm{ab}}$ & $70,44^{\mathrm{a}}$ & $59,44^{\mathrm{a}}$ \\
BGT ( $\left.{ }^{\circ} \mathrm{C}\right)$ & $85,18^{\mathrm{a}}$ & $84,50^{\mathrm{a}}$ & $82,90^{\mathrm{a}}$ \\
\hline
\end{tabular}

Means followed by the same letter in the line do not differ by Tukey test at $5 \%$ probability. FR = Respiratory Rate, $\mathrm{HR}=$ heart rate and index globe temperature and humidity (BGT).

The significant difference observed in white $\left(59,44^{\mathrm{b}}\right)$, this implies in explaining the equine white or cream color, reflecting a greater proportion of heat through infrared waves, consequently less heat absorbing than the hair red or black. 
In Table 3, it was found that FR positively correlated with FC (0.65), this can be explained due to the horses were suffering heat stress because of physical exercise, thus providing the use of various mechanisms of thermal regulation for the thermolysis excessive body heat, this relationship evapotranspiration and vasodilatation were used together in a ratio of $65 \%$. Second ( Silva et al., 2005) When the exercise is performed in a hot environment, heat loads are produced by imposing greater demands on the thermoregulatory function, requiring redistribution of heat to the skin targeting heat loss, resulting an increase in heart rate (McConaghy, 1994).

The SHIFT positively correlated with FC $(0.80)$ and FR $(0.71)$, showing that as the shift changed it provided a change in these thermoregulatory mechanisms, in this study it was observed that late shifts have greater influence homeothermy in animals, these being more stressful for the animals as seen in Table 1. Second (Ridgway, 1994) heart rate can be used as an indicator to determine the level of compliance and the ability of the animal to continue work or exercise.

Table 3. Correlation between thermoregulatory characteristics and meteorological variables crossbred horses of Quarter Horse during shifts (morning and afternoon) on the Redemption Gurguéia PI

\begin{tabular}{lcccccc}
\hline Char. & FR & BGT & TG & TURN & CP & AGE \\
\hline FC & 0,65 & 0,27 & $-0,80$ & 0,80 & $-0,10$ & 0,02 \\
FR & & 0,15 & $-0,71$ & 0,71 & $-0,17$ & $-0,10$ \\
BGT & & $-0,31$ & 0,31 & $-0,22$ & 0,01 \\
TG & & & $-1,00$ & 0,00 & 0,00 \\
TURN & & & & 0,00 & 0,00 \\
CP & & & & & 0,16 \\
\hline
\end{tabular}

Color Coat (CP), Respiratory Rate (FR), Heart Rate (HR), Globe Temperature (TG).

The temperature of the globe (TG) negatively correlated with respiratory frequency FR $(-0.71)$ and heart rate HR $(-0.80)$, indicating that the animals could possibly be using other mechanisms such as sweating or rectal temperature as the main forms heat loss. The SHIFT also negatively correlated with TG $(-1.00)$ due to the difference between shifts which also thermoregulatory characteristics described in Table 01 can be observed. Freitas (2005) states that as the sweating is the primary means of cooling in exercising horses in the respiratory tract beyond their normal duties, must also contribute to heat loss.

The BGT positively correlated with FC (0.27) and SHIFT ( 0.31$)$, as BGT Amenta promotes an increase in the need for animals to seek ways to eliminate internal heat and HR was used as the BGT increased main change in the morning shift to afternoon. The efficiency of sweating is directly related to the temperature and air humidity, which will interfere with the rate of sweat evaporation and thus heat loss, Freitas (2005).

\section{Conclusion}

Horses evaluated during competitions Rodeo Cow showed physiological changes as a result of physical exercise and the associated stress, suggesting the lack of a proper training routine and inhospitable environmental conditions of parks Rodeo Cow.

\section{Acknowledgment}

I want to thank, first of all to God for strength and courage throughout this long journey. I also thank all the teachers who have accompanied me during graduation especially my tutor Dr. Severino Cavalcante de Sousa Junior.

\section{References}

Angeli, A. L. (2005). Efeito da aquacupuntura sobre a performance de cavalos puro sangue-inglês treinados, em pista e avaliados por meio do teste de velocidade escalonada a campo. $107 \mathrm{f}$. Tese (Doutorado em Medicina Veterinária) - Faculdade de Medicina Veterinária e Zootecnia, Universidade Estadual Paulista, Botucatu.

Brasil, L. H. de A., Wechsler, F. S., Baccari Júnior, F., Gonçalves, H. C., \& Bonassi, I. A. (2000). Efeitos do estresse térmico sobre a produção, composição química do leite e respostas termorreguladoras de cabras da raça Alpina. Revista Brasileira de Zootecnia, 29, 1632-1641. http://dx.doi.org/10.1590/S1516-35982000000600006 
Cunningham, J. G. (2004). Termorregulação. In Tratado de fisiologia veterinária (3 ed.). Rio de Janeiro: Guanabara Koogan.

Freitas, E. V. V. (2005). Fisiologia do exercício físico de equinos. Anais do ZOOTEC'2005 - 24 a 27 de maio de 2005 - Campo Grande-MS.

Harvey, W. R. (1960). Least squares analysis of data with unequal suclass numbers. Beltsville, Md: ARS/USDA, Publ.

Hinchcliff, K. W. (2002). High intensity exercise conditioning increases accumulated oxygen deficit of horses. Equine Veterinary, 34(1), 9-16. http://dx.doi.org/10.2746/042516402776181150

Lopes, K. R. F., Batista, J. S., Dias, R. V. C., \& Soto-Blanco, B. (2009). Influência das competições de vaquejada sobre os parâmetros indicadores de estresse em eqüinos. Ciência Animal Brasileira, 10(2), 538-543.

Marc, M., Parvizi, N., Ellendorff, F., Kallweit, E., \& Elsaesser, F. (2000). Plasma cortisol and ACTH concentrations in the warmblood horse in response to a standardized treadmill exercise test as physiological markers for evaluation of training status. Journal of Animal Science, 78, 1936-1946.

Marques M. S. (2002). Influência do exercício físico sobre níveis de lactato plasmático e cortisol sérico em cavalos de corrida [dissertação]. São Paulo: Faculdade de Medicina Veterinária e Zootecnia. Universidade de São Paulo.

McConaghy, F. (1994). Thermoregulation. In D. R. Hodgson, \& R. J. Rose (Eds.), The athletic horse: principles and practice of equine sports medicine (1 ed.). W.B. Saunders Company.

Mota, S. D. M. (2000). Genética nas pistas. Revista Unesp - Rural, 17, 22.

Oliveira, L. A., Campelo, J. E. G., Azevedo, D. M. M. R., Costa, A. P. R., Turco, S. H. N., \& Moura, J. W. S. (2008). Estudo de respostas fisiológicas de eqüinos sem raça definida e da raça quarto de milha às condições climáticas de Teresina, Piauí. Ciência Animal Brasileira, 9(4), 827-838.

Paludo, G. R., Mcmanus, C., Melo, R. Q., Cardoso, A. G., Mello, F. P. S., Moreira, M., \& Fuck, B. H. (2002). Efeito do Estresse Térmico e do Exercício sobre Parâmetros Fisiológicos de Cavalos do Exército Brasileiro. Revista Brasileira de Zootecnia, 31(3), 1130-1142. http://dx.doi.org/10.1590/S1516-35982002000500009

Ridgway, K. J. (1994). Training endurance horses. In D. H. Hodgson, R. J. Rose (Eds.), Principles and practice of equine sports medicine: The athletic horse (1 ed., pp. 409-428). W.B. Saunderss Company.

Sas Institute, SAS. (2003). Statistical Analysis System. User's Guide. Cary, NC: SAS Institute Inc.

Silva, L. D., Santos, S. A., Silva, R. A. S., McMANUS, C., \& Petzold, H. (2005). Adaptação do cavalo pantaneiro ao estresse da lida diária de gado no Pantanal, Brasil. Archivos de zootecnia, 54(206-207), 509-513.

Silva, R. (2005). Zoneamento bioclimático para animais de interesse zootécnico. Anais da 42 a Reunião Anual da Sociedade Brasileira de Zootecnia, Goiânia, GO: SBZ, 388-394.

Silva, R. G. (2000). Introdução à Bioclimatologia Animal. São Paulo: Nobel.

Trilk, J. L., Lindner, A. J., Greene, H. M., Alberghina, D., \& Wickler, S. J. (2002). A lactate - guided conditioning programme to improve endurance performance. Equine Veterinary Journal, 34(S34), 122-125. http://dx.doi.org/10.1111/j.2042-3306.2002.tb05403.x

\section{Copyrights}

Copyright for this article is retained by the author(s), with first publication rights granted to the journal.

This is an open-access article distributed under the terms and conditions of the Creative Commons Attribution license (http://creativecommons.org/licenses/by/3.0/). 